Article

\title{
Protective Effect of Quercetin, a Flavonol against Benzo(a)pyrene-Induced Lung Injury via Inflammation, Oxidative Stress, Angiogenesis and Cyclooxygenase-2 Signalling Molecule
}

\author{
Mohammad A. Alzohairy ${ }^{1}$, Amjad Ali Khan ${ }^{2}{ }^{\mathbb{D}}$, Mohammad Azam Ansari ${ }^{3} \mathbb{D}$, Ali Yousif Babiker $^{1}$, \\ Mohammed A. Alsahli ${ }^{1}$ (D), Saleh A. Almatroodi ${ }^{1}$ (D) and Arshad Husain Rahmani ${ }^{1, *}$ \\ 1 Department of Medical Laboratories, College of Applied Medical Sciences, Qassim University, \\ Buraydah 51452, Saudi Arabia; zhiery@qu.edu.sa (M.A.A.); ababkr@qu.edu.sa (A.Y.B.); \\ shly@qu.edu.sa (M.A.A.); smtrody@qu.edu.sa (S.A.A.) \\ 2 Department of Basic Health Sciences, College of Applied Medical Sciences, Qassim University, \\ Buraydah 51452, Saudi Arabia; akhan@qu.edu.sa \\ 3 Department of Epidemic Disease Research, Institute for Research \& Medical Consultations (IRMC), \\ Imam Abdulrahman Bin Faisal University, Dammam 31441, Saudi Arabia; maansari@iau.edu.sa \\ check for \\ * Correspondence: ah.rahmani@qu.edu.sa
} updates

Citation: Alzohairy, M.A.; Khan, A.A.; Ansari, M.A.; Babiker, A.Y; Alsahli, M.A.; Almatroodi, S.A.; Rahmani, A.H. Protective Effect of Quercetin, a Flavonol against Benzo(a)pyrene-Induced Lung Injury via Inflammation, Oxidative Stress, Angiogenesis and Cyclooxygenase-2 Signalling Molecule. Appl. Sci. 2021, 11, 8675. https://doi.org/10.3390/ app11188675

Academic Editors: Antonios

E. Koutelidakis and Haralabos

C. Karantonis

Received: 8 August 2021

Accepted: 14 September 2021

Published: 17 September 2021

Publisher's Note: MDPI stays neutral with regard to jurisdictional claims in published maps and institutional affiliations.

Copyright: (c) 2021 by the authors. Licensee MDPI, Basel, Switzerland. This article is an open access article distributed under the terms and conditions of the Creative Commons Attribution (CC BY) license (https:/ / creativecommons.org/licenses/by/ $4.0 /)$.

\begin{abstract}
Quercetin $(\mathrm{Qu})$ is an important polyphenolic flavonoid which exhibits tremendous antioxidant, anti-inflammatory and other health promoting effects. The aim of the current study was to explore the therapeutic role of $\mathrm{Qu}$ on benzo(a)pyrene $[\mathrm{B}(\mathrm{a}) \mathrm{P}]$-induced lung injury in rats. $\mathrm{B}(\mathrm{a}) \mathrm{P}$ was given to the rats at dose of $50 \mathrm{mg} / \mathrm{kg}$ b.w. for continues 8 weeks through oral gavage. The rats were treated with $\mathrm{Qu}$ at dose of $50 \mathrm{mg} / \mathrm{kg}$ b.w prior $30 \mathrm{~min}$ before the oral administration of $\mathrm{B}(\mathrm{a}) \mathrm{P}$. The effects of $\mathrm{Qu}$ were studied by measuring the level of lactate dehydrogenase (LDH), anti-oxidant enzymes, lipid peroxidation, inflammatory cytokines, lung tissues architecture and expression of cyclooxygenase-2 (COX-2). The level of pro-inflammatory cytokines such as IL-1 $\beta$ ( 27.30 vs. $22.80 \mathrm{pg} / \mathrm{mL}$ ), IL-6 (90.64 vs. $55.49 \mathrm{pg} / \mathrm{mL}$ ) and TNF- $\alpha$ (56.64 vs. $40.49 \mathrm{pg} / \mathrm{mL}$ ) increased significantly and antioxidant enzymes decreased significantly in benzopyrene-induced lung injury in comparison to the control group. The treatment with $\mathrm{Qu}$ potentially reversed the effects of $\mathrm{B}(\mathrm{a}) \mathrm{P}$ to a great extent, as it led to the enhancement of antioxidant enzymes and decreased proinflammatory cytokines level. A significant surge of VEGF level was noticed in the B(a)P group as compared to the control group, while the Qu treatment groups exhibited less angiogenesis as lower level of VEGF levels, compared with the B(a)P treatment group. The Qu treatment significantly decreased the degrees of histopathological changes and collagen deposition in B(a)P-induced lung injury. The $\mathrm{B}(\mathrm{a}) \mathrm{P}$-treated group showed higher cytoplasmic expression of COX-2 protein, which significantly decreased in the Qu treatment group. These outcomes recommend an effective role of $\mathrm{Qu}$ in the protection of lung injury against $\mathrm{B}(\mathrm{a}) \mathrm{P}$ through the regulation of the inflammatory factors, oxidative stress and the maintenance lung tissue architecture.
\end{abstract}

Keywords: quercetin; lung injury; inflammation; oxidative stress; angiogenesis; benzopyrene; COX-2 protein

\section{Introduction}

The lung associated diseases are among the major cause of deaths worldwide including United States, India, and Saudi Arabia. The major causative agents of the lung pathogenesis include tobacco smoking. According to the World Health Organization (WHO), 1 in 10 deaths worldwide is caused by tobacco use, and each year almost 7 million deaths occur. If this consumption patterns remain same, by 2030, almost 8 million people will die from this habit $[1,2]$. Smoking in women leads to the risk of osteoporosis, cervical 
cancer, atherosclerosis, cardiovascular disease, lung cancer, type 2 diabetes, premature menopause and premature birth [3,4]. Cigarette smoking causes more deaths from respiratory, vascular and other neoplastic diseases than from lung cancer alone. The risks of almost all noncommunicable diseases (cerebrovascular disease, ischemic heart disease, chronic lung disease, diabetes, cirrhosis, pneumonia and cancers of the pancreas, lung, esophagus and mouth are reported to be higher in smokers than in nonsmokers [5-8].

Tobacco comprises a high amount Benzopyrene [B(a)P], a well-known polycyclic aromatic hydrocarbon, usually formed in great amounts by high-temperature processing of foods, including fried chicken, as well as smoked foods [9] (Figure 1). Polycyclic aromatic hydrocarbons (PAHs) including $\mathrm{B}(\mathrm{a}) \mathrm{P}$ is formed from cooking with oils heated at high temperature.

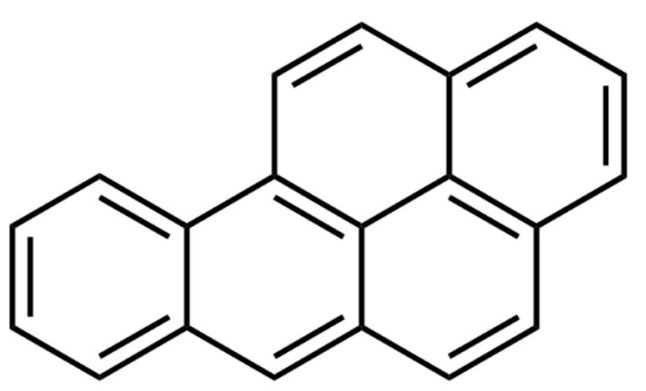

Figure 1. The chemical structure of Benzopyrene.

The excessive exposure of $\mathrm{B}(\mathrm{a}) \mathrm{P}$ displays its role in physiological and structural changes in lungs [10-12]. Moreover, it also causes pulmonary inflammation, surfactant dysfunction and edema [13]. B(a)P is metabolized to form various types of reactive oxygen species (ROS) that induce lipid oxidation and reduce antioxidant enzymes. Increases in the ROS level in various types of diseases including cancer leads to tumor promotion and progression, as ROS is involved in signaling and metabolic pathways and also causes DNA mutation [14,15].

The use of alternative medication based on natural resources such as herbal and plant products are now commonly suggested to be used as modern therapeutic applications. These medicines have a strong potential to inhibit the disease development and progression, including cancer [16]. The natural compounds or active compounds of the medicinal plants play a significant role in the management of diseases through the modulation of various biological activities. Moreover, the phytochemicals show positive effects on human health through various mechanisms, such as epigenetic modifications, metabolic and signal transduction pathways and the regulation of antioxidant enzyme activity $[17,18]$.

Moreover, different bioactive herbal compounds are used in human clinical trials, as an adjuvant with some antitumor therapies to minimize the adverse effects such as nausea and fatigue [19].

The main benefit of such alternative-medicine-based therapies lies in its low cost, fewer side effects and wide distribution [20]. Quercetin ((2-(3,4-dihydroxyphenyl)-3,5,7trihydroxy-4-Hchromen-4-one)), a dietary flavanol, is an important polyphenolic flavonoid occurring in fruits and vegetables and its role in health management has been proven previously [21,22] (Figure 2). It is widely found in different fruits and vegetables [23].

The results confirm that $\mathrm{Qu}$ shows antioxidant [24], anti-inflammatory [25] and anticancer effects [26]. Qu performs a noteworthy effect in tumors and other diseases through the modulation of various cell signaling pathways. Quercetin is reported to induce p21(inhibitor of cyclin-dependent kinase) activation, a well-known cyclin-dependent kinase (CDK) inhibitor, and induces damage in DNA and the activation of checkpoint kinase 2 (Chk2) [27]. Qu is also known to inhibit the proliferation and activation of survivin (pro-apoptotic biomarker) in ovarian tumor cells [28]. The objective of the current study was to explore the role of $\mathrm{Qu}$ against benzopyrene-induced lung pathogenesis in animal 
models by studying lipid peroxidation, angiogenic factors, inflammation, oxidative stress and lung tissue architecture. In addition collagen fiber formation, ultrastructural changes and expressional pattern of COX-2 protein is also evaluated.<smiles>O=c1c(O)c(-c2ccc(O)c(O)c2)oc2cc(O)cc(O)c12</smiles>

Figure 2. The chemical structure of Quercetin.

\section{Materials and Methods}

\subsection{Chemicals}

Benzopyrene and quercetin were procured from Sigma Aldrich, St. Louis, MO, USA. The lactate dehydrogenase (LDH) and antioxidant status assays kits such as total antioxidant capacities (TAOC), catalase (CAT), reduced glutathione (GSH) and glutathione-Stransferase (GST) were measured calorimetrically by kits purchased from Abcam, Cambridge, UK. The inflammatory markers such as interleukin (IL)-1 $\beta$, interleukin-6 (IL-6) and tumor necrosis factor-alpha (TNF- $\alpha$ ) were estimated by using ELISA kits (Abcam, Cambridge, UK). Primary antibodies cyclooxygenase-2 used in this study were purchased from Abcam, Cambridge, UK. Masson trichrome kits were purchased from Abcam, Cambridge, UK. All supplementary reagents used in this study were of high purity grade obtained from commercial sources.

\subsection{Animals}

In this study, 32 male wistar albino rats (175-225 g) were used, purchased from King Saud University, Saudi Arabia. The animals were kept for one week for acclimatization to minimize any transportation stress. The animals were kept in a climatically controlled animal house with room temperature of $23 \pm 2{ }^{\circ} \mathrm{C}$ under $12 \mathrm{~h} / 12 \mathrm{~h}$ light/dark cycle and $45-65 \%$ relative humidity. Maximum efforts were made to minimize the suffering of animals.

All the experimental procedures were approved by the ethics committee of Qassim University, College of Applied Medical Sciences for Animal Experiments (No. CAMS12019-2-2-I-5553). The ethical committee of the Qassim University is in accordance to the guidelines of National Institutes of Health (NIH), USA.

\subsection{Sample Preparation}

The Quercetin was dissolved in $0.5 \%$ DMSO in aqueous solution with mixing so the DMSO concentration was $0.1 \%$

\subsection{Animal Grouping and Treatment Plan}

The rats were randomly distributed into four groups ( $n=8$ per group) and treatment plan is mentioned in Table 1 as follows: 
Table 1. Animal grouping and treatment plan.

\begin{tabular}{|c|c|c|c|}
\hline Group Number & Group Description & Short Name & Treatment Plan \\
\hline 1 & Normal Control & NC & $\begin{array}{l}\text { The animals received normal saline solution }(400 \mu \mathrm{L}) \text { through oral } \\
\text { gavage for } 8 \text { consecutive weeks }\end{array}$ \\
\hline 2 & Disease control & $\mathrm{B}(\mathrm{a}) \mathrm{P}$ & $\begin{array}{c}\text { Oral administration of B(a)P in olive oil }(50 \mathrm{mg} / \mathrm{kg} \text { b.w.) }(400 \mu \mathrm{L}) \\
3 \text { times / week for } 8 \text { consecutive weeks [29]. }\end{array}$ \\
\hline 3 & $\begin{array}{l}\text { Disease control + } \\
\text { treatment }\end{array}$ & $\mathrm{Qu}+\mathrm{B}(\mathrm{a}) \mathrm{P}$ & $\begin{array}{c}\mathrm{Qu}(50 \mathrm{mg} / \mathrm{kg} \text { b.w.), } 400 \mu \mathrm{L} \text { was given orally } 30 \mathrm{~min} \text { before the oral } \\
\text { administration of B(a)P in olive oil ( } 50 \mathrm{mg} / \mathrm{kg} \mathrm{b.w.)} 3 \text { times/week } \\
\text { for } 8 \text { consecutive weeks [30] }\end{array}$ \\
\hline 4 & Treatment control & $\mathrm{Qu}$ & $\begin{array}{c}\text { The rats received Qu }(400 \mu \mathrm{L}) 3 \text { times a week at a dose of } 50 \mathrm{mg} / \mathrm{kg} \\
\text { b.w. for } 8 \text { consecutive weeks }\end{array}$ \\
\hline
\end{tabular}

The vehicle volume was the same in all experimental groups. The treatment plan on animals was continued for 8 consecutive weeks. During the treatment plan, the animals were keenly observed, and all the animals survived after the completion of treatment plan. Figure 3 indicates the biochemical and histopathological analysis.

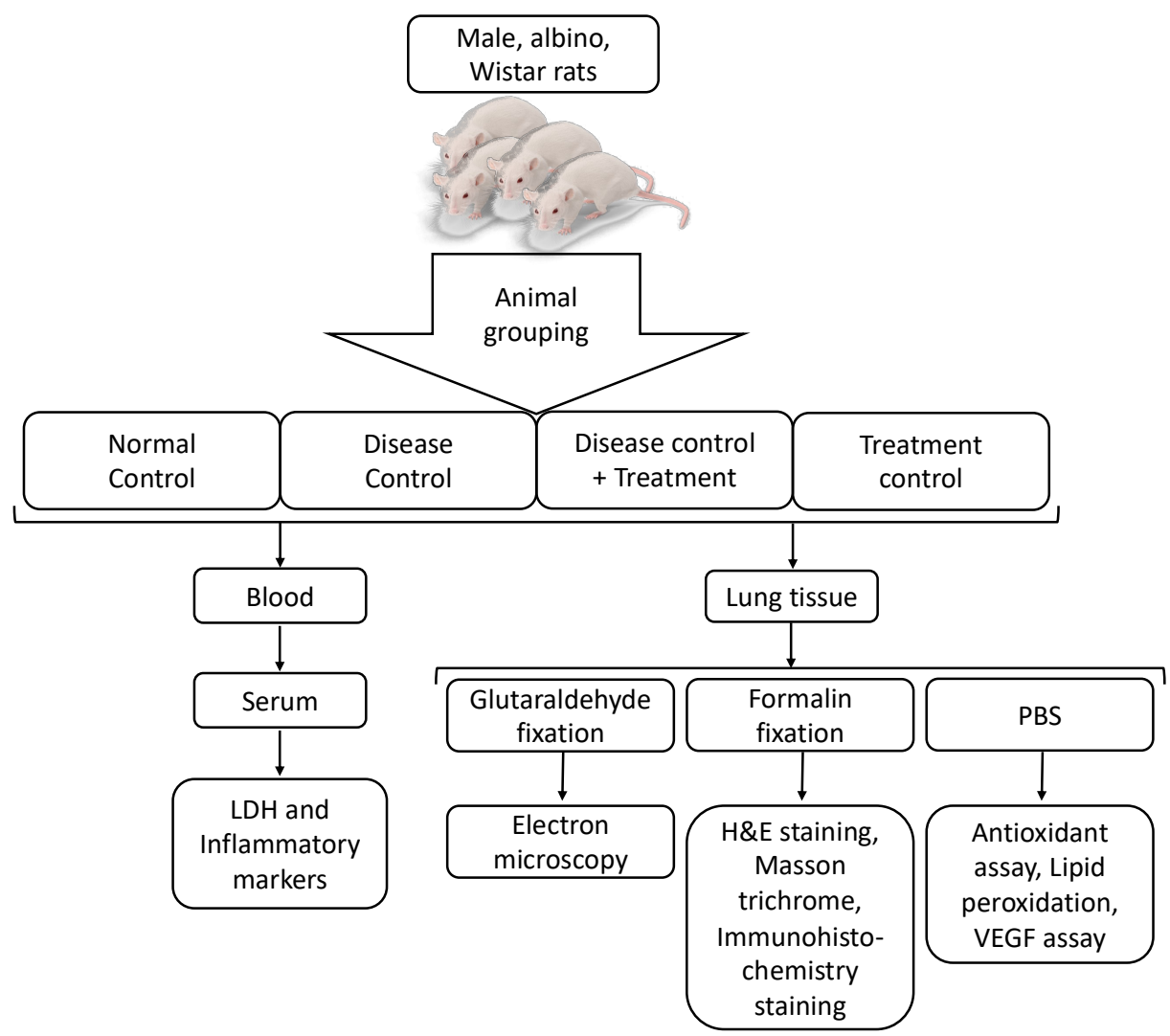

Figure 3. Flow chart showing different biochemical and histopathological analysis.

At the end of the treatment plan, all rats were given urethane injection $(1.5 \mathrm{~g} / \mathrm{kg}$ i.p. $)$ to induce fast and deep anesthesia. The rats were positioned on a board with pins to avoid it from moving. The dissection was started from the lower part to neck region, to reveal the epidermis/upper skin. The rib cage was cut throughout the sternum to retrieve the lungs. The blood samples were collected just after sacrifice. The blood samples were kept at room temperature for $30 \mathrm{~min}$ in plain blood collection tubes. All the clotted blood samples were centrifuged at $3000 \mathrm{rpm}$ for $10 \mathrm{~min}$, the serum was separated and its aliquots were stored at $-20{ }^{\circ} \mathrm{C}$ for further evaluation. 


\subsection{Measurement of Inflammatory Marker}

The Interleukin-1 $\beta$ (IL-1 $\beta$ ), tumor necrosis factor-alpha (TNF- $\alpha$ ) and IL-6 were measured by taking serum samples using quantitative ELISA kits (Abcam, U.K) by following the manufacturer's instructions. All the samples (standard, control and samples) were run in duplicate and the average absorbance was taken for calculations.

\subsection{Lactate Dehydrogenase (LDH) Assay}

Lactate dehydrogenase (LDH) was assayed calorimetrically on serum samples by using Abcam kit following the manufacturer's instructions. All the samples (standard, control and samples) were run in duplicate and the average absorbance was taken for calculations.

\subsection{Tissue Sampling}

The lungs from all the animals were removed immediately after the sacrifice of animals and were washed with ice-cold saline solution. One portion of lung was homogenized in potassium phosphate buffer ( $\mathrm{pH}$ 7.4) using tissue homogenizer. The homogenate was centrifuged at $4{ }^{\circ} \mathrm{C}$ for $10 \mathrm{~min}$ at $10,000 \mathrm{rpm}$. The supernatant samples were stored at $-20{ }^{\circ} \mathrm{C}$ for biochemical analysis.

\subsection{Measurement of Lipid Peroxidation}

The lipid peroxidation in lung tissues were indirectly measured by estimating the level of malondialdehyde (MDA) through thiobarbituric acid reactive substance (TBARS) assay by using kit from Abcam. The calculation was performed as moles of MDA per gram of tissue used. All the samples (standard, control and samples) were run in duplicate and the average absorbance was taken for calculations.

\subsection{Measurement of Antioxidant Enzymes}

The antioxidant enzymes such as glutathione S-transferase (GST), catalase and reduced glutathione (GSH) were measured in the lung tissues and all the result were interpreted accordingly. The serum levels of total antioxidant capacity (TAOC) were estimated as per the protocol provided by manufacturer (Abcam, Cambridge, UK). All the samples (standard, control and samples) were run in duplicate and the average absorbance was taken for calculations.

\subsection{Angiogenic Marker Measurement}

The level of VEGF, a well-known signaling protein marker for angiogenesis and promoting new blood vessels growth was measured in the lung tissue by an Elisa kit obtained from Abcam, Cambridge, UK, as per manufacturers instruction. All the samples (standard, control and samples) were run in duplicate and the average absorbance was taken for calculations.

\subsection{Histopathological Evaluation}

For histopathological evaluation, one portion of each lung sample was collected and immediately fixed in formalin (10\%). The tissue samples were processed by using automated tissue processor. The lung tissues were embedded in paraffin wax, $5 \mu \mathrm{m}$ thin sections were cut and staining was accomplished by using Mayer's hematoxylin and eosin (H\&E) staining to examine the lung tissue's architecture. The tissue samples were deparaffinized by xylene and the slides were rehydrated by using distilled water. The Mayer's hematoxylin was used for $1 \mathrm{~min}$ to stain the slides. The slides were immediately washed with running tap water. The counter staining was performed by using alcoholic eosin for $1 \mathrm{~min}$. The dehydration was performed by using 3 changes of $95 \%$ ethyl alcohol and 2 changes of absolute alcohol. Moreover, the tissue clearance was performed by using 3 changes of xylene. The tissue samples were mounted by using DPX. The tissues were examined by light microscope. The lung tissue sections were also run for Masson's 
trichrome staining (Abcam, Cambridge, UK) to examine the collagen fibers following the protocol as:

The kit items were equilibrated to room temperature just prior to use and were gently agitated. The tissue sections were deparaffinized and hydrated in distilled water. The Bouin's fluid was preheated in water bath to $56-64{ }^{\circ} \mathrm{C}$. The slides were preheated in Bouin's fluid for $60 \mathrm{~min}$ followed by a $10 \mathrm{~min}$ cooling period. The slides were rinsed in tap water until section was completely clear, followed by rinsing once in distilled water. Equal parts of Weigert's (A) and Weigert's (B) were mixed and slides were stained with working Weigert's iron Hematoxylin for $5 \mathrm{~min}$. The slides were rinsed in running tap water for $2 \mathrm{~min}$. Biebrich Scarlet/Acid Fuchsin Solution were applied to slide for $15 \mathrm{~min}$, followed by rinsing the slides in distilled water. The slides were then differentiated in Phosphomolybdic/Phosphotungstic acid solution for 10-15 min or until collagen was not red. Without rinsing, aniline blue solution was applied to slide for 5-10 min followed by rinsing in distilled water. Acetic Acid Solution (1\%) was applied to slides for 3-5 min. The slides were dehydrated very quickly in 2 changes of $95 \%$ alcohol, followed by 2 changes of absolute alcohol. The slides were cleared in Xylene and were mounted with DPX resin. All the slides were analyzed by under light microscope (Eclipse Ni-E; Nikon Corporation, Tokyo, Japan) and the results were interpreted accordingly.

\subsection{Ultrastructural Assessment}

For ultrastructure evaluation, thinner lung samples were selected and straightaway fixed in $2.5 \%$ glutaraldehyde and were then transferred to osmium tetroxide. Briefly, all the tissues were properly dehydrated, cleared and suitably embedded in epoxy resin, and ultra-microtome was used to obtain semi-thin sections. Uranyl acetate and lead citrate were used to stain the ultrathin sections, followed as per the procedure of Hayat [31], and were photographed under transmission electron microscopy (TEM) (TEM, JEOL JEM-1230, JEOL Ltd., Tokyo, Japan) and the significant results were consequently interpreted.

\subsection{Immunohistochemical Staining}

The immunohistochemistry staining was performed according to the previously described methods [32-34]. The cyclooxygenase-2 (COX-2) protein expression was measured on lung sections by using biotin-streptavidin method as per the manufacturer's protocol. The primary antibodies were used to measure the expression pattern of COX-2 protein among all experimental groups. All the slides were incubated overnight with primary antibodies, followed by one hour treatment with biotinylated antibodies as secondary antibodies. All the slides were properly washed with phosphate buffer and were further incubated for $30 \mathrm{~min}$. with streptavidin peroxidase. The COX-2 expression was visualized by using diaminobenzidine kit (Abcam, Cambridge, UK). Finally, the slides were counterstained with hematoxylin.

The expressional pattern was evaluated by using light microscope and the results were interpreted as based on COX-2 cytoplasmic expression. The quantification of the cytoplasmic expression of COX-2 protein was performed by a pathologist blinded to the different animal groups. The total of 500 cells were counted at high magnification after identifying at low power in the 5 selected regions. The positively stained cells were expressed as percentage of total number of cells counted in each case and the results are presented as $\pm \mathrm{SD}$.

\subsection{Statistical Analysis}

The data obtained from all experimental groups were expressed as standard error of mean (SEM). Statistical package for social sciences (SPSS) software was used to evaluate the differences between different groups. One-way analysis of variance (ANOVA) was applied to check the statistically significant differences and $p<0.05$ was considered to be statistically significant. 


\section{Results}

\subsection{The Effect of Quercetin on LDH Levels}

Lactate dehydrogenase (LDH) was measured in all experimental groups and the results indicated a significant increase in serum $\mathrm{LDH}$ in $\mathrm{B}(\mathrm{a}) \mathrm{P}$ group $(3591.2 \pm 243.07 \mathrm{U} / \mathrm{L})$ $(p<0.05)$ as compared to the control group rats $(2137.8 \pm 110.06 \mathrm{U} / \mathrm{L})$ (Figure 4). Pretreatment with quercetin considerably lowered the levels of serum lactate dehydrogenase $(2674.2 \pm 176.41 \mathrm{U} / \mathrm{L})$ in comparison to the $\mathrm{B}(\mathrm{a}) \mathrm{P}$ group. The finding reveals that quercetin reduces the toxicity marker levels in the group of diseased experimental rats.

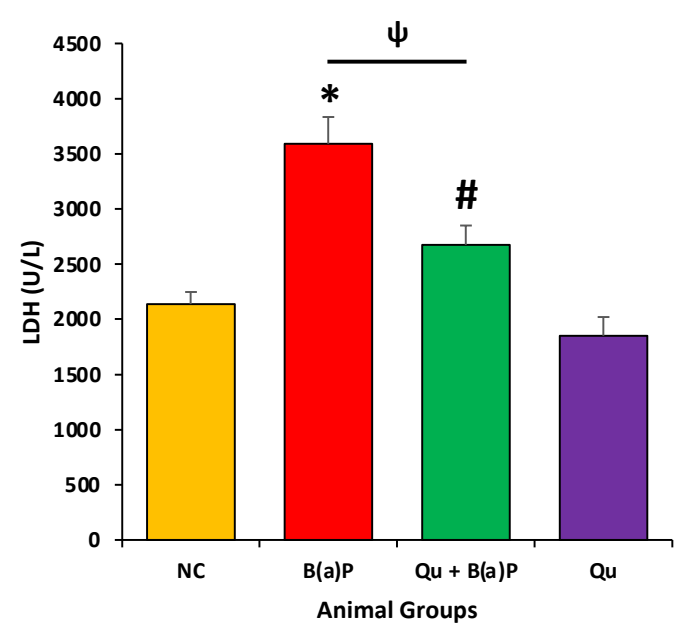

Figure 4. LDH activity of serum samples in different groups of experimental animals. The values indicate the mean \pm SEM, with eight animals/group. In comparison to the normal control group animals, the LDH activity showed significant increase in disease control (B(a)P-treated) rats. The $\mathrm{Qu}$ treatment considerably reduced the enhanced level of $\mathrm{LDH}$ in $\mathrm{Qu}+\mathrm{B}(\mathrm{a}) \mathrm{P}$ animal group. The statistically significant differences $(p<0.05)$ are denoted as asterisk $\left.{ }^{*}\right)$ between NC and B(a)P groups and (\#) between NC and $\mathrm{Qu}+\mathrm{B}(\mathrm{a}) \mathrm{P}$ group. The bar between $\mathrm{B}(\mathrm{a}) \mathrm{P}$ and $\mathrm{Qu}+\mathrm{B}(\mathrm{a}) \mathrm{P}$ group indicated with psi $(\psi)$ denotes significant difference $(p<0.05)$ between these two groups.

\subsection{Effects of $Q u$ on Inflammatory Markers}

Benzopyrene-caused lung damage is also categorized by an inflammatory response due to pro-inflammatory cytokines such as IL- $1 \beta$, IL- 6 and TNF- $\alpha$ activity [35]. The protective role of quercetin against $\mathrm{B}(\mathrm{a}) \mathrm{P}$-induced injury was examined through the measurement of pro-inflammatory cytokines. In comparison to the control group, the level of pro-inflammatory cytokines, IL-1 $\beta(27.30 \pm 1.2 \mathrm{ng} / \mathrm{mL}), \mathrm{IL}-6(90.64 \pm 3.0 \mathrm{pg} / \mathrm{mL})$ and TNF- $\alpha$ (56.64 $\pm 2 \mathrm{pg} / \mathrm{mL}$ ) increased significantly in the B(a)P group (Figure 5), while these parameters were significantly decreased with pre-treatment with quercetin as compared with the $\mathrm{B}(\mathrm{a}) \mathrm{P}$ group. These observations reveal that quercetin attenuates the lung inflammation/injury and also decreases the level of pro-inflammatory cytokines induced by $\mathrm{B}(\mathrm{a}) \mathrm{P}$ treatment.

\subsection{Quercetin Effect on Antioxidant Enzymes and Malondialdehyde (MDA)}

The result revealed that the $\mathrm{B}(\mathrm{a}) \mathrm{P}$ treatment significantly decreased the antioxidant enzymes, including Catalase $(18.2 \pm 2 \mathrm{U} / \mathrm{mg})$ and glutathione S-transferase (GST) $(84.9 \pm 10 \mathrm{mU} / \mathrm{mg})$, and reduced glutathione (GSH) $(24.9 \pm 2 \mu \mathrm{mol} / \mathrm{g})$ and the total antioxidant capacity $(75.3 \pm \mathrm{nM})(p<0.05)$ levels as compared to the control group (Figure 6). Pre-treatment with quercetin at $50 \mathrm{mg} / \mathrm{kg}$ b.w. significantly increased the level of antioxidant enzymes, including Catalase $(24.6 \pm 1 \mathrm{U} / \mathrm{mg}$ ) and glutathione S-transferase (GST) $(128.4 \pm 9 \mathrm{mU} / \mathrm{mg})$, and reduced glutathione (GSH) $(30.4 \pm 3 \mu \mathrm{mol} / \mathrm{g})$ and the total antioxidant capacity $(126.3 \pm 4 \mathrm{nM})$ compared with the B(a)P treatment $(p<0.05)$. 

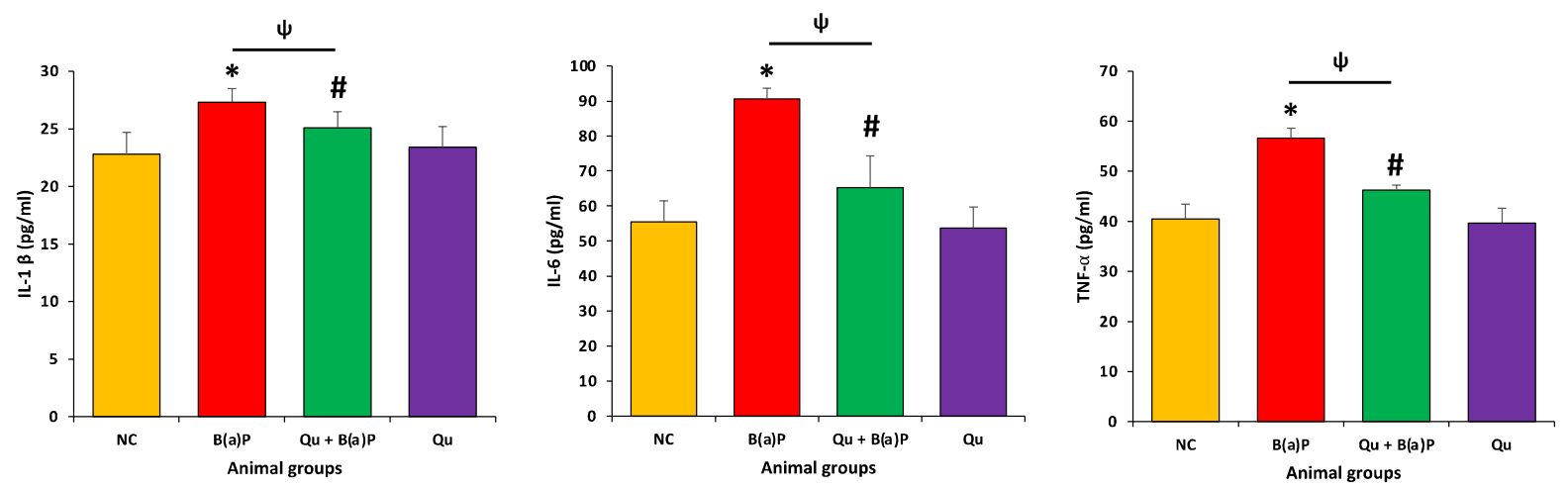

Figure 5. The graphical presentation of various inflammatory marker levels of serum samples in different animal groups. The values indicate the mean \pm SEM, with eight animals/group. The treatment with B(a)P only led to enhanced levels of TNF- $\alpha$, IL-1 $\beta$ and IL-6, as compared to NC animals. The treatment with Qu significantly reduced the enhanced level of these inflammatory markers in $\mathrm{Qu}+\mathrm{B}(\mathrm{a}) \mathrm{P}$ animal group $(p<0.05)$. The statistically significant differences $(p<0.05)$ are represented by an asterisk $\left(^{*}\right)$ between the $\mathrm{NC}$ and $\mathrm{B}(\mathrm{a}) \mathrm{P}$ groups and (\#) between the $\mathrm{NC}$ and $\mathrm{Qu}+\mathrm{B}(\mathrm{a}) \mathrm{P}$ groups. The bar between the $\mathrm{B}(\mathrm{a}) \mathrm{P}$ and $\mathrm{Qu}+\mathrm{B}(\mathrm{a}) \mathrm{P}$ groups indicated with psi $(\psi)$ denotes significant difference $(p<0.05)$ between these two groups.
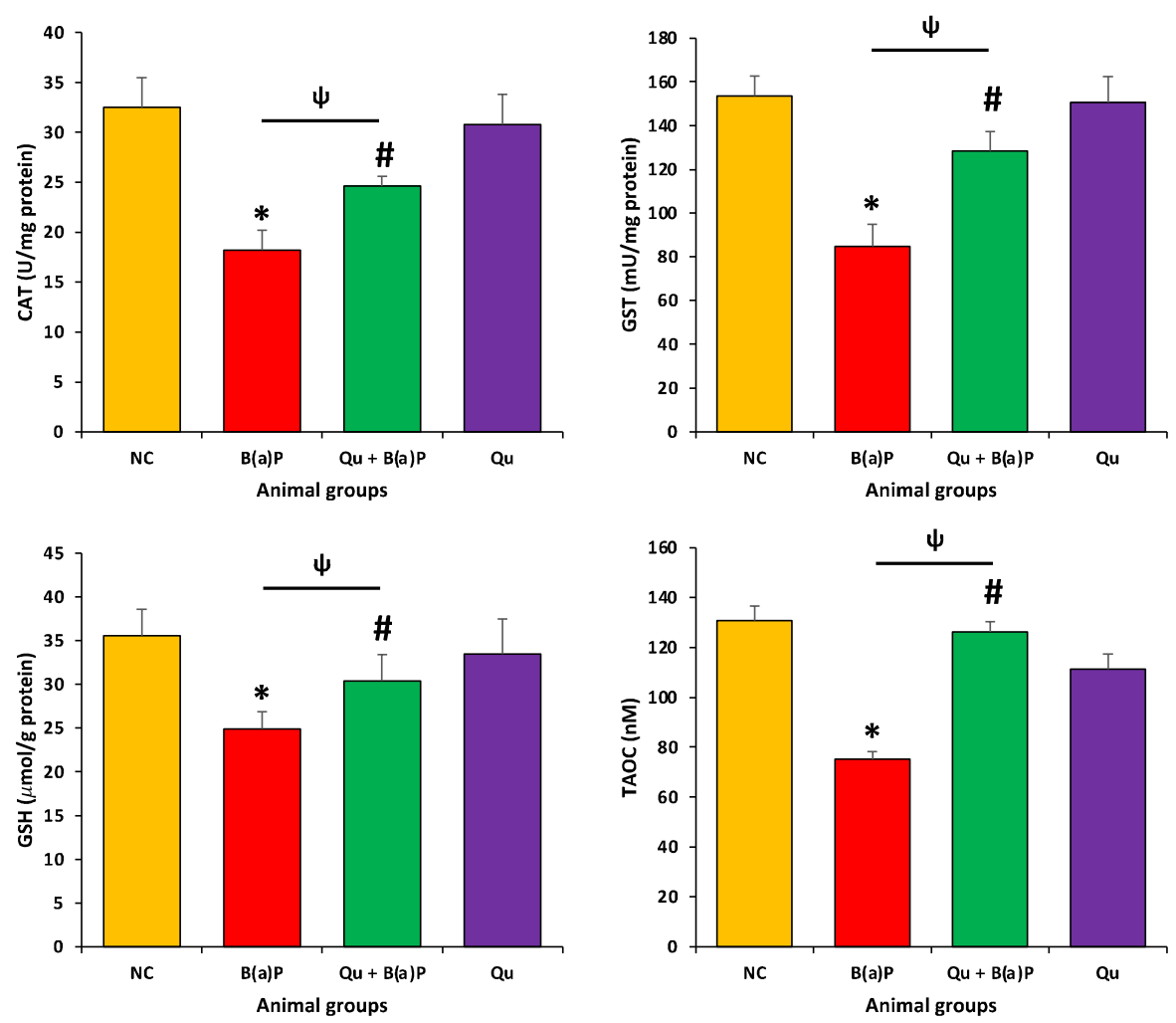

Figure 6. The graphical presentation of various antioxidant enzymes, Catalase, glutathione S-transferase (GST) and reduced glutathione (GSH) of lung tissue sample and total antioxidant capacity in serum samples of different animal groups. The values indicate the mean \pm SEM, with eight animals/group. The treatment with B(a)P only led to reduction in the levels of these antioxidant enzymes or antioxidant status as compared to NC animals. The treatment with Qu significantly enhanced the level of these reduced inflammatory markers in $\mathrm{Qu}+\mathrm{B}(\mathrm{a}) \mathrm{P}$ animal group $(p<0.05)$. The statistically significant differences $(p<0.05)$ are represented by an asterisk $\left(^{*}\right)$ between the NC and B(a)P groups and (\#) between the NC and $\mathrm{Qu}+\mathrm{B}(\mathrm{a}) \mathrm{P}$ groups. The bar between the $\mathrm{B}(\mathrm{a}) \mathrm{P}$ and $\mathrm{Qu}+\mathrm{B}(\mathrm{a}) \mathrm{P}$ groups indicated with psi $(\psi)$ denotes significant difference $(p<0.05)$ between these two groups. 
Malondialdehyde (MDA) is an important biomarker of oxidative stress [36]. Moreover, $\mathrm{B}(\mathrm{a}) \mathrm{P}$ exposure to rats show a significant enhancement in lung MDA levels $(153.3 \pm 3 \mathrm{nmol})$ as compared to the control group $(113.7 \pm 6 \mathrm{nmol})$. Treatment with quercetin significantly decreased the MDA levels $(127.3 \pm 4 \mathrm{nmol})$ in the lung injury rats (Figure 7$)$.

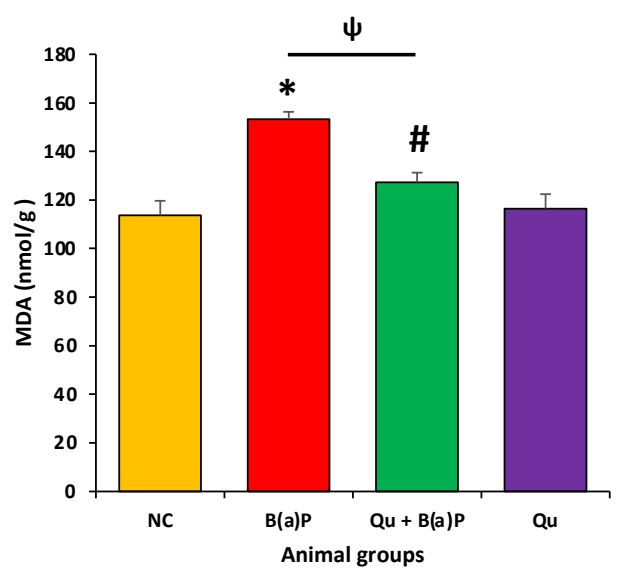

Figure 7. The graphical presentation of various lipid peroxidation (MDA) level in lung tissue samples of different animal groups. The values indicate the mean \pm SEM, with eight animals/group. The intoxication with $\mathrm{B}(\mathrm{a}) \mathrm{P}$ led to increased level of MDA as compared to NC animals. The treatment with $\mathrm{Qu}$ significantly reduced the MDA level $(p<0.05)$. The statistically significant differences $(p<0.05)$ are represented by an asterisk $\left(^{*}\right)$ between the NC and $\mathrm{B}(\mathrm{a}) \mathrm{P}$ groups and (\#) between the $\mathrm{NC}$ and $\mathrm{Qu}+\mathrm{B}(\mathrm{a}) \mathrm{P}$ groups. The bar between the $\mathrm{B}(\mathrm{a}) \mathrm{P}$ and $\mathrm{Qu}+\mathrm{B}(\mathrm{a}) \mathrm{P}$ groups indicated with psi $(\psi)$ denotes significant difference $(p<0.05)$ between these two groups.

\subsection{Effect of Quercetin on VEGF}

The level of VEGF in B(a)P group (4256 $\pm 243.07 \mathrm{pg} / \mathrm{g}$ tissue) exhibited significant elevation as compared to the control rats ( $2947 \pm 190.06 \mathrm{pg} / \mathrm{g}$ tissue). The treated groups with Qu showed a significant reduction in VEGF level (3569 $\pm 220.41 \mathrm{pg} / \mathrm{g}$ tissue) compared to $\mathrm{B}(\mathrm{a}) \mathrm{P}$-intoxicated group (Figure 8 ). These results reveal that quercetin attenuates the inflammation of lungs and also decreases the angiogenic factor induced by $\mathrm{B}(\mathrm{a}) \mathrm{P}$ in rats.

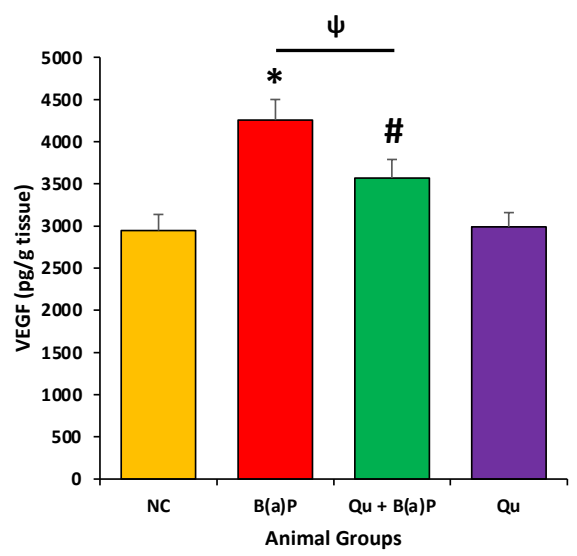

Figure 8. The graphical presentation of VEGF level in lung tissue samples of different animal groups. The values indicate the mean \pm SEM, with eight animals/group. The intoxication with B(a)P only led to increased level of VEGF as compared to NC animals. The treatment with Qu significantly reduced the VEGF level $(p<0.05)$. The significant differences $(p<0.05)$ are represented by an asterisk $\left(^{*}\right)$ between the NC and $\mathrm{B}(\mathrm{a}) \mathrm{P}$ groups and (\#) between the $\mathrm{NC}$ and $\mathrm{Qu}+\mathrm{B}(\mathrm{a}) \mathrm{P}$ groups. The bar between the $\mathrm{B}(\mathrm{a}) \mathrm{P}$ and $\mathrm{Qu}+\mathrm{B}(\mathrm{a}) \mathrm{P}$ groups indicated with psi $(\psi)$ denotes significant difference $(p<0.05)$ between these two groups. 


\subsection{Effects of Quercetin on Lung Histology}

The protective role of quercetin $(50 \mathrm{mg} / \mathrm{kg} \mathrm{b} . \mathrm{w})$ was observed against $\mathrm{B}(\mathrm{a}) \mathrm{P}$-induced lung injury. From all the experimental animal groups, the lung tissues were analyzed by H\&E staining to observe the histological findings. The histological analysis clearly indicated that the control group section had a normal lung tissue architecture. The $\mathrm{B}(\mathrm{a}) \mathrm{P}-$ treated group demonstrated major destruction of alveolar architecture, inflammatory cell infiltrate, hemorrhage and congestion (Figure 9), although these changes were observed to be considerably less than the mild inflammatory cell infiltrate in the pretreatment of the quercetin-treated group, and this indicates that quercetin protects against $\mathrm{B}(\mathrm{a}) \mathrm{P}$-induced lung injury.

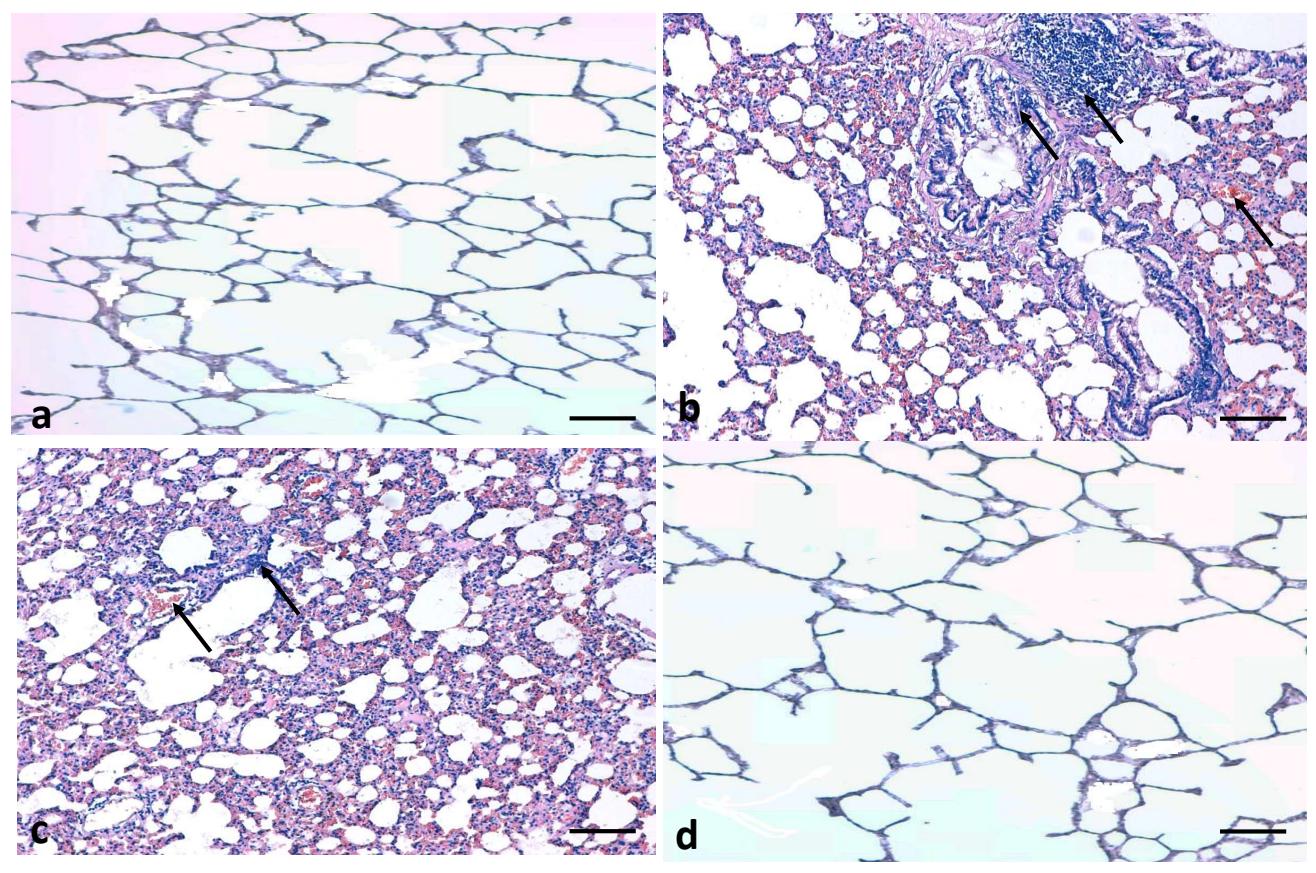

Figure 9. Influence of $\mathrm{Qu}$ treatment in histopathological changes of lung tissues. (a): Control animal group lung architecture. (b): B(a)P-treated group shows severe destruction of alveolar architecture, inflammatory cell infiltrate, hemorrhage and congestion. (c): The changes were observed to be significantly less in co-administration of Qu plus B(a)P-treated group. (d): Qu-only treatment animals displayed normal lung architecture (Scale bar $=100 \mu \mathrm{m})$.

\subsection{Effects of Quercetin on Lung Fibrosis}

Collagen deposition in experimental groups of rat lungs was examined using Masson's Trichrome. It was noticed that compared to the control group, B(a)P induced severe collagen deposition in lung tissues (Figure 10). However, collagen fiber deposition was found to be significantly less in quercetin pretreatment group, thus indicating that $\mathrm{B}(\mathrm{a}) \mathrm{P}$ damage is minimized by quercetin treatment, whereas the control group and the Quercetin-only treated rats groups showed normal collagen distributions. However, this finding advocates that quercetin plays an important role in the inhibition of fibrosis. 


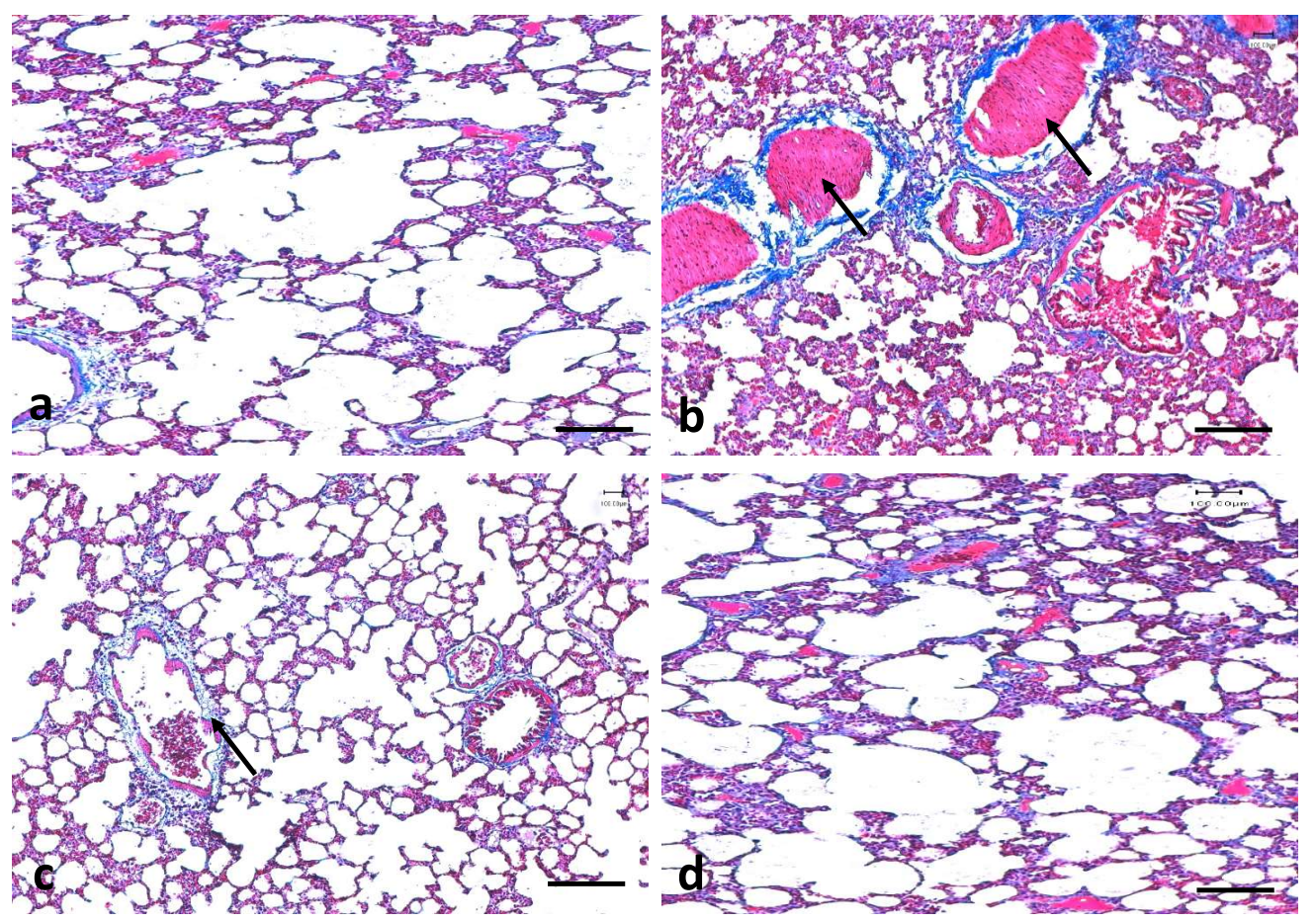

Figure 10. Effect of Qu in lung fibrosis, (a): control animal lungs reveal normal fiber architecture, (b): severe collagen deposition is induced by B(a)P administration, (c): Qu showed suppression of B(a)P-induced fibrosis, (d): Normal collagen in Qu only treated group. (Scale bar $=100 \mu \mathrm{m}$ ).

\subsection{Protective Role of Qu on Lung Tissue Ultrastructure}

With the help of transmission electron microscopy (TEM), the ultrastructural variations of the lungs were investigated. The control group samples demonstrated a normal gas barrier facing alveolar lumen (AS). Furthermore, the RBCs are observed in the capillary lumen and low vacuolization, and normal Type I and type II cells (PnI and PnII) are also observed (Figure 8). In the $\mathrm{B}(\mathrm{a}) \mathrm{P}$-treated group, various types of alterations were seen (Figure 11). The B(a)P-intoxicated rats treated with $\mathrm{Qu}$ displayed less or normal organelle structures.

\subsection{Effects of Quercetin on COX-2 Expression}

COX-2 protein expression was examined using immunohistochemistry, and expression patterns were compared accordingly. The B(a)P-treated group showed shows high cytoplasmic expression of COX-2 protein, whereas the control group did not show any expression (Figure 12). As a result of the treatment with quercetin, a significant decrease in COX-2 protein expression $(p<0.05)$ was observed as compared with the $\mathrm{B}(\mathrm{a}) \mathrm{P}$-treated group. 

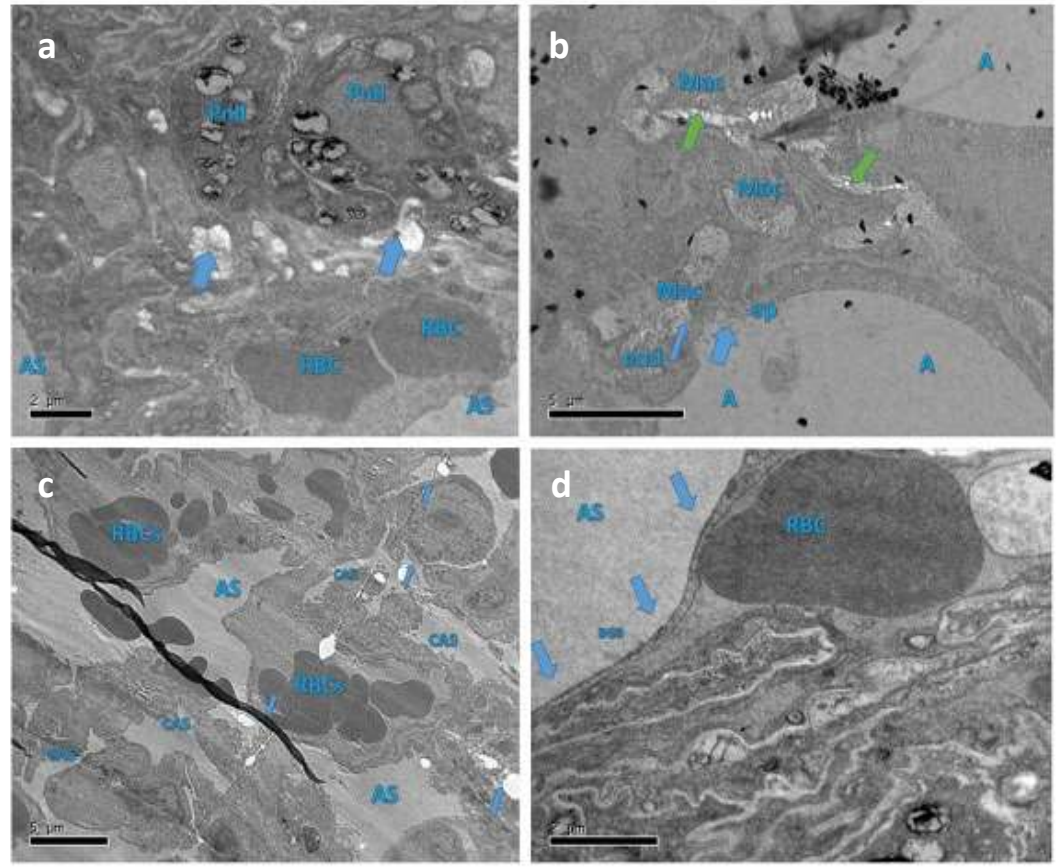

Figure 11. Electron microscope images of different animal group (a) the control group lung samples show normal gas barrier facing alveolar lumen (AS), RBCs are observed in the capillary lumen, low vacuolization and normal type I and type II cells (PnI and PnII) are also observed; (b) In the B(a)P treatment group, alveolar epithelial cell (PnII), gas-barrier-facing alveolar lumen (A), formed by discontinuous layer of squamous alveolar cell (type I) cytoplasm. The fused basal laminae is interrupted (arrow), and the cytoplasm of the capillary endothelium is swollen (end). The ruptured multinucleated, macrophage (mac) and the cytoplasmic contents (thick arrow) escape into the alveolar lumen (A); lung showing compression of the inter-alveolar spaces, which is represented as green arrow; (c) B(a)P-intoxicated rats treated with Qu showed RBCs as seen in the capillary lumen, constriction of alveolar spaces (CAS), vacuolization (arrow) and Alveolar space (AS); (d) Qu only (50 mg/kg bw) treated group: Normal gas barrier facing alveolar lumen (AS), red blood cells are seen in the capillary lumen (RBC). (Scale bar $=2-5 \mu \mathrm{m})$.

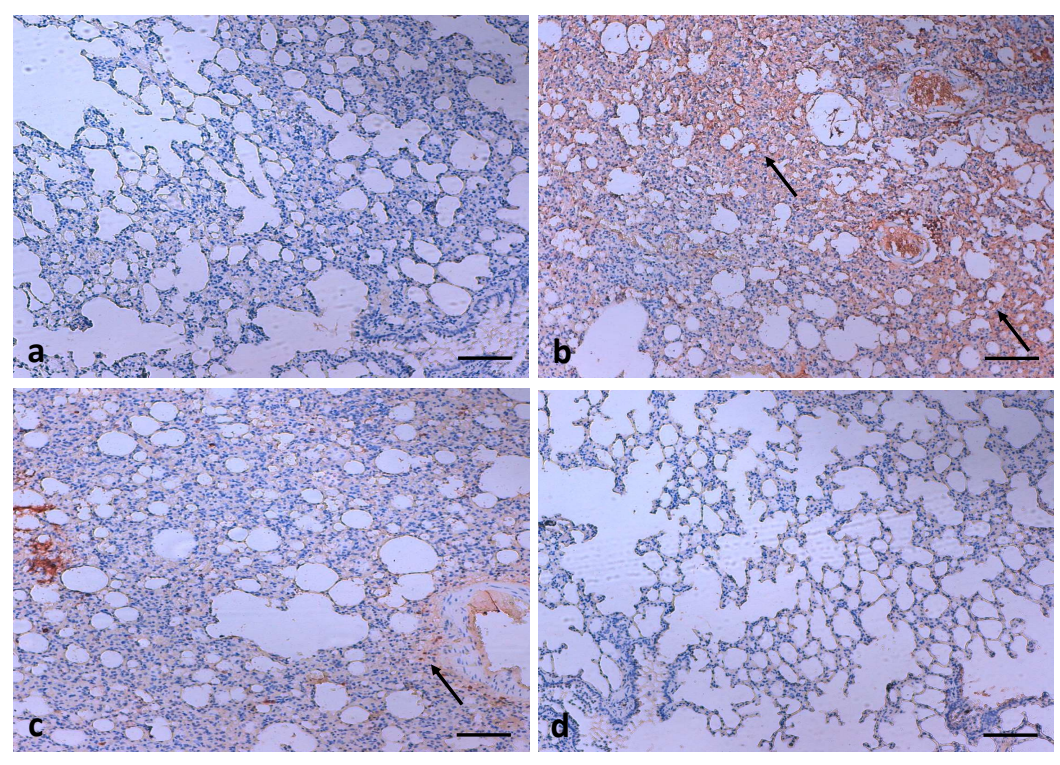

Figure 12. The analysis of COX-2 protein expression (a) The COX-2 protein is not observed control animal group; (b) B(a)P treated group showed high cytoplasmic expression of this protein; (c) the low expression of COX-2 protein observed in the $\mathrm{B}(\mathrm{a}) \mathrm{P}$ plus Qu treated group; (d) the rats treated with Qu only do not show any COX-2 protein expression. (Scale bar = $100 \mu \mathrm{m})$. 


\section{Discussion}

To better understand the link between lung injury and inflammation, the lung injury rats models were developed by using benzopyrene $(\mathrm{B}(\mathrm{a}) \mathrm{P})$. Benzopyrene is a potent carcinogen and plays a significant role in the initiation of lung injury and the development and progression of cancer. Plant-based phenolic compounds have demonstrated a significant role in cancer management, chiefly by controlling reactive oxygen species (ROS) level $[37,38]$. In the current study, it was found that a significant increase in serum lactate dehydrogenase $(\mathrm{LDH})$ occurs in rats by the intoxication of $\mathrm{B}(\mathrm{a}) \mathrm{P}$ as compared to that of control rats, whereas the Qu pre-treatment significantly reduced the levels of serum lactate dehydrogenase compared with the $\mathrm{B}(\mathrm{a}) \mathrm{P}$ group. One study reported that the $\mathrm{B}(\mathrm{a}) \mathrm{P}$-treated group showed a significant increase in serum LDH when compared to the control group. Carvacrol pretreatment significantly decreased toward the normal [39]. Another study has reported that $\mathrm{B}(\mathrm{a}) \mathrm{P}$ increases the level of $\mathrm{LDH}$ in lung injury animal models, whereas glycyrrhizic acid shows a protective role through the suppression of LDH level [12] and $\mathrm{B}(\mathrm{a}) \mathrm{P}$ causes liver pathogenesis [40]

Another study based on mice models reported that $\mathrm{B}(\mathrm{a}) \mathrm{P}$ increases the level of MDA [41]. In addition, a notable increase in LDH activity and MDA level was observed after $\mathrm{B}(\mathrm{a}) \mathrm{P}$ treatment, which was reduced with naringenin treatment recommending its protective role on lung epithelium cells [42].

It was reported that inflammation, due to the expression of inflammatory cytochemokines such as interleukin (IL)-6 and tumor necrosis factor-alpha (TNF)- $\alpha$ ), shows a significant role in lung injury onset $[43,44]$. Furthermore, the development of lung inflammation is matched by the activation, expression, and secretion of several pro-inflammatory mediators from the lung parenchyma and vascular cells such as cytokines, leukotriene, and adhesion molecules [45].

It was noticed that Qu meaningfully decreased the levels of inflammatory markers, which certainly improved the inflammation in lung injury caused by $\mathrm{B}(\mathrm{a}) \mathrm{P}$ and might be the reason for Qu regulating the production of IL- $\beta$, IL- 6 and TNF- $\alpha$ and preventing the formation of lung pathogenesis. It has been reported that lipopolysaccharide increases the inflammatory markers, which are counteracted by the quercetin pretreatment [46].

TNF- $\alpha$, IL- $\beta$ and IL-6 levels was high in the B(a)P-only treatment group animals in comparison to the control group. Whereas the pre-treatment with quercetin importantly decreased such inflammatory markers in comparison to the disease control group. Some previous studies have also demonstrated that inflammatory marker is enhanced in the $\mathrm{B}(\mathrm{a}) \mathrm{P}$ group. Moreover, it was observed that a $\mathrm{B}(\mathrm{a}) \mathrm{P}$ plus curcumin treatment significantly lowers the inflammatory cytokines such as TNF- $\alpha$, IL-6 and C-reactive protein (CRP) levels [47]. Another finding revealed that B(a)P administration raises the levels of lung injury markers. Naringenin treatment attenuated the levels of oxidative stress by restoring antioxidant enzymes and significantly decreases the inflammatory responses. Meanwhile, naringenin excellently decreased the expression of NF- $\mathrm{kB}$ and COX-2 induced by $\mathrm{B}(\mathrm{a}) \mathrm{P}$ intoxication [42].

In the present study, it was observed that $\mathrm{B}(\mathrm{a}) \mathrm{P}$ treatment significantly decreased the antioxidant enzymes levels as compared to control group. Pre-treatment with Qu significantly increased the antioxidant enzyme level compared with the $\mathrm{B}(\mathrm{a}) \mathrm{P}$ treatment. Moreover, $\mathrm{B}(\mathrm{a}) \mathrm{P}$ treatment rats showed a significant increase in lung MDA levels as compared to the control group. Treatment with Qu significantly decreased MDA levels in the lung injury rats. The current finding was in accordance with previous finding that reported a decrease in the level of antioxidant enzymes after $\mathrm{B}(\mathrm{a}) \mathrm{P}$ treatment [48]. In addition, another study demonstrated that $\mathrm{B}(\mathrm{a}) \mathrm{P}$ treatment causes a decrease in antioxidant proteins. Whereas, the treatment with diosmin restored the antioxidant status significantly [49].

In the current study, compared with the control group, $\mathrm{B}(\mathrm{a}) \mathrm{P}$ treatment showed that VEGF levels were significantly higher $(p<0.05)$. Compared with the $\mathrm{B}(\mathrm{a}) \mathrm{P}$ group, the $\mathrm{Qu}-$ treated group showed significantly lower $(p<0.05)$ VEGF levels. A previous study reported that a significant increase in the VEGF level in B(a)P group compared with control group, 
while the $C$. ignea treatment group showed lower levels [50]. Another study reported that the VEGF level was high in the $\mathrm{B}(\mathrm{a}) \mathrm{P}$-treated group [29]. VEGF-induced tube formation of RF/6A cells and its migration importantly inhibited by quercetin in a dose-dependent manner [51].

The lung sections of control animals showed a normal architecture of cells with small uniform nuclei. Benzopyrene-treated animal lung tissue shows loss of architecture with infiltration of inflammatory cells, hemorrhages and congestion. However, these changes were observed to be significantly fewer as mild inflammatory cell intrude in the Qu pretreatment group, and this demonstrates that $\mathrm{Qu}$ protects the lung against $\mathrm{B}(\mathrm{a}) \mathrm{P}$ damage. The previous results demonstrate that $\mathrm{B}(\mathrm{a}) \mathrm{P}$ administration caused severe destruction of the alveolar architecture and necrosis of the alveolar epithelium [13]. Similarly, other findings reported that histological sections of the control group showed normal lung tissue architecture. The $\mathrm{B}(\mathrm{a}) \mathrm{P}$-treated group shows destruction of the alveolar architecture, and diosmin protects the lung against $\mathrm{B}(\mathrm{a}) \mathrm{P}$ damage [49]. The $\mathrm{B}(\mathrm{a}) \mathrm{P}$ administration in rats cause various types of changes in the tissue as thickening of the lung epithelium, alveolar architecture damage and increased infiltration of inflammatory cells. Moreover, the other changes such as congestion, fibrosis and hemorrhage have also been noticed in B(a)P-treated groups [52].

The ultrastructural changes observed that the $\mathrm{B}(\mathrm{a}) \mathrm{P}$-treated group exhibited various types of alterations. The B(a)P-intoxicated rats treated with $\mathrm{Qu}$ displayed less changes or normal organelles structures.

It was noticed that $\mathrm{B}(\mathrm{a}) \mathrm{P}$ induced severe collagen deposition in lung tissues, thus indicating an interstitial fibrosis as compared with the control. Whereas the control group and Qu-treated rats showed normal collagen distribution. However, this finding advocates that Qu plays an important role in the inhibition of fibrosis. A previous study described that lung cancer bearing animals induced by $\mathrm{B}(\mathrm{a}) \mathrm{P}$ showed increased collagen deposition. Pretreatment with Capsaicin markedly reduced collagen accumulation, thereby preserving the near-normal architecture [53].

In the $\mathrm{B}(\mathrm{a}) \mathrm{P}$-treated group, various types of alterations were seen such as the formation of a damaged discontinuous layer of squamous alveolar cells cytoplasm. The fused basal laminae are interrupted and the cytoplasm of the capillary endothelium is swollen, ruptured, multinucleated and the lung shows compression of the interalveolar spaces which appears as clefts. B(a)P-intoxicated rats treated with Qu displayed less or normal organelles structures. The $\mathrm{B}(\mathrm{a}) \mathrm{P}$-treated group showed high cytoplasmic expression of COX-2 protein, whereas Qu treatment significantly decrease the COX-2 protein expression.

Previous study based on benzopyrene reported that B(a)P-treated lung cell stained positive by antibodies against COX-2. Moreover, Rutin pretreatment significantly reduced expression in a dose-dependent manner [54]. Another study has demonstrated that significantly increased expression of proinflammatory markers (NF-kB, IL-6 and COX-2) in $\mathrm{B}(\mathrm{a}) \mathrm{P}$-treated mice as compared to vehicle-treated mice [49]. In addition, some other studies reported that COX-2 protein distribution was upregulated LPS administration; this was mainly in neutrophils, alveolar macrophages and alveolar epithelial type II cells. However, pretreatment with quercetin efficiently prevented the increase of COX-2 [55]. B[a]P significantly enhances the expressional pattern of NF-kB, COX-2 and IL-6. The pretreatment with Diosmin significantly reduced the damage to lung epithelium and alveolar architecture and reduced the inflammatory cell infiltration in the lung tissues [49]

\section{Conclusions}

In conclusion, the present study demonstrated that Qu significantly showed lung protective effects via the reduction in inflammatory markers and lactate dehydrogenase (LDH) levels in rats with $\mathrm{B}(\mathrm{a}) \mathrm{P}$-induced lung injury. The current study revealed that Qu has also a high antioxidant potential and plays a vital role in the protection of lung pathogenicity against free radicals. The results demonstrate that $\mathrm{Qu}$ treatment significantly decrease the degrees of histopathological changes and collagen fiber deposition. These findings provide 
significant results to support the lung protective activity of Qu through modulating various biological activities. However, further studies based on in vivo and in vitro observations are required to explore the efficacy and molecular mechanisms underlying the protective effects of $\mathrm{Qu}$ in $\mathrm{B}(\mathrm{a}) \mathrm{P}$-induced lung pathogenesis.

Author Contributions: Conceptualization, M.A.A. (Mohammad A. Alzohairy), A.A.K. and A.H.R.; methodology, A.A.K. and A.H.R.; software, A.A.K. and A.H.R.; validation, S.A.A. and M.A.A. (Mohammed A. Alsahli); formal analysis, M.A.A. (Mohammed A. Alsahli) and A.Y.B.; investigation, M.A.A. (Mohammad Azam Ansari), A.A.K. and A.H.R.; writing-original draft preparation, M.A.A. (Mohammad A. Alzohairy), A.A.K. and A.H.R.; writing-review and editing, M.A.A. (Mohammad A. Alzohairy), M.A.A. (Mohammad Azam Ansari) and S.A.A.; supervision, M.A.A. (Mohammed A. Alsahli) and S.A.A.; project administration, M.A.A. (Mohammad A. Alzohairy) and S.A.A. All authors have read and agreed to the published version of the manuscript.

Funding: This work was funded and supported by the Deanship of Scientific Research, Qassim University (Grant No. CAMS1-2019-2-2-I-5553).

Institutional Review Board Statement: The animals were maintained at animal facility of the College of Applied Medical Sciences (CAMS) accordance with the guidelines of the Qassim University on Animal Care. The animal experiments were carried out as per the guidelines of CAMS, Qassim University and approved by the Institutional Animal Ethics Committee (2019-2-2-I-5553), CAMS, Qassim University.

Informed Consent Statement: Not applicable.

Data Availability Statement: The data used to support the findings of this study are included within the article.

Conflicts of Interest: All authors declare that they have no conflict of interest.

\section{References}

1. Organization WHO. WHO Report on the Global Tobacco Epidemic, 2017: Monitoring Tobacco use and Prevention Policies; World Health Organization: Geneva, Switzerland, 2017.

2. Organization WHO. WHO Report on the Global Tobacco Epidemic, 2011: Warning About the Dangers of Tobacco; World Health Organization: Geneva, Switzerland, 2011.

3. Islami, F.; Torre, L.A.; Jemal, A. Global trends of lung cancer mortality and smoking prevalence. Transl. Lung. Cancer Res. 2015, 4, 327-338.

4. Szkup, M.; Jurczak, A.; Karakiewicz, B.; Kotwas, A.; Kopeć, J.; Grochans, E. Influence of cigarette smoking on hormone and lipid metabolism in women in late reproductive stage. Clin. Interv. Aging. 2018, 13, 109. [CrossRef]

5. Chen, Z.; Peto, R.; Zhou, M.; Iona, A.; Smith, M.; Yang, L.; Guo, Y.; Chen, Y.; Bian, Z.; Lancaster, G.; et al. Contrasting male and female trends in tobacco-attributed mortality in China: Evidence from successive nationwide prospective cohort studies. Lancet 2015, 386, 1447-1456. [CrossRef]

6. Pirie, K.; Peto, R.; Reeves, G.K.; Green, J.; Beral, V.; Collaborators MWS. The 21st century hazards of smoking and benefits of stopping: A prospective study of one million women in the UK. Lancet 2013, 381, 133-141. [CrossRef]

7. Doll, R.; Peto, R.; Boreham, J.; Sutherland, I. Mortality in relation to smoking: 50 years' observations on male British doctors. BMJ 2004, 328, 1519. [CrossRef]

8. Doll, R.; Hill, A.B. The mortality of doctors in relation to their smoking habits. BMJ 1954, 1, 1451. [CrossRef] [PubMed]

9. Phillips, D.H. Polycyclic aromatic hydrocarbons in the diet. Mutat. Res. 1999, 443, 139-147. [CrossRef]

10. Jahangir, T.; Sultana, S. Benzo(a)pyrene induced genotoxicity: Attenuation by farnesol in a mouse model. J. Enzym. Inhib. Med. Chem. 2008, 23, 888-894. [CrossRef] [PubMed]

11. Islam, J.; Shree, A.; Vafa, A.; Afzal, S.M.; Sultana, S. Taxifolin ameliorates Benzo[a]pyrene-induced lung injury possibly via stimulating the Nrf2 signalling pathway. Int. Immunopharmacol. 2021, 96, 107566. [CrossRef]

12. Baumgartner, K.B.; Samet, J.M.; Stidley, C.A.; Colby, T.V.; Waldron, J.A. Cigarette smoking: A risk factor for idiopathic pulmonary fibrosis. Am. J. Respir. Crit. Care. Med. 1997, 155, 242-248. [CrossRef] [PubMed]

13. Qamar, W.; Khan, A.Q.; Khan, R.; Lateef, A.; Tahir, M.; Rehman, M.U.; Ali, F.; Sultana, S. Benzo(a)pyrene-induced pulmonary inflammation, edema, surfactant dysfunction, and injuries in rats: Alleviation by farnesol. Exp. Lung. Res. 2012, 38, 19-27. [CrossRef]

14. Diwanji, N.; Bergmann, A. An unexpected friend-ROS in apoptosis-induced compensatory proliferation: Implications for regeneration and cancer. Semin. Cell. Dev. Biol. 2018, 80, 74-82. [CrossRef] [PubMed]

15. He, L.; He, T.; Farrar, S.; Ji, L.; Liu, T.; Ma, X. Antioxidants maintain cellular redox homeostasis by elimination of reactive oxygen species. Cell. Physiol. Biochem. 2017, 44, 532-553. [CrossRef] [PubMed] 
16. Choi, W.H.; Chu, J.P.; Jiang, M.H.; Baek, S.H.; Park, H.D. Effects of fraction obtained from Korean Corni Fructus extracts causing anti-proliferation and p53-dependent apoptosis in A549 lung cancer cells. Nutr. Cancer 2011, 63, 121-129. [CrossRef]

17. Ratovitski, E. Anticancer natural compounds as epigenetic modulators of gene expression. Curr. Genom. 2017, 18, 175-205. [CrossRef] [PubMed]

18. Pratheeshkumar, P.; Sreekala, C.; Zhang, Z.; Budhraja, A.; Ding, S.; Son, Y.O.; Wang, X.; Hitron, A.; Hyun-Jung, K.; Wang, L.; et al. Cancer prevention with promising natural products: Mechanisms of action and molecular targets. Anti Cancer Agents Med. Chem. 2012, 12, 1159-1184. [CrossRef] [PubMed]

19. Costea, T.; Hudiță, A.; Ciolac, O.A.; Gălățeanu, B.; Ginghină, O.; Costache, M.; Ganea, C.; Mocanu, M.M. Chemoprevention of colorectal cancer by dietary compounds. Int. J. Mol. Sci. 2018, 19, 3787. [CrossRef]

20. Rostock, M.; Naumann, J.; Guethlin, C.; Guenther, L.; Bartsch, H.H.; Walach, H. Classical homeopathy in the treatment of cancer patients-A prospective observational study of two independent cohorts. BMC Cancer 2011, 11, 19. [CrossRef]

21. Anand David, A.V.; Arulmoli, R.; Parasuraman, S. Overviews of Biological Importance of Quercetin: A Bioactive Flavonoid. Pharmacogn. Rev. 2016, 10, 84-89.

22. Dabeek, W.M.; Marra, M.V. Dietary quercetin and kaempferol: Bioavailability and potential cardiovascular-related bioactivity in humans. Nutrients 2019, 11, 2288. [CrossRef]

23. Panche, A.N.; Diwan, A.D.; Chandra, S.R. Flavonoids: An overview. J. Nutr. Sci. 2016, 5, e47. [CrossRef]

24. Song, X.; Wang, Y.; Gao, L. Mechanism of antioxidant properties of quercetin and quercetin-DNA complex. J. Mol. Model. 2020, 26, 133. [CrossRef]

25. Saeedi-Boroujeni, A.; Mahmoudian-Sani, M.R. Anti-inflammatory potential of Quercetin in COVID-19 treatment. J. Inflamm. 2021, 18, 3. [CrossRef]

26. Vafadar, A.; Shabaninejad, Z.; Movahedpour, A.; Fallahi, F.; Taghavipour, M.; Ghasemi, Y.; Akbari, M.; Shafiee, A.; Hajighadimi, S.; Moradizarmehri, S.; et al. Quercetin and cancer: New insights into its therapeutic effects on ovarian cancer cells. Cell. Biosci. 2020, 10, 32. [CrossRef] [PubMed]

27. Jeong, J.H.; An, J.Y.; Kwon, Y.T.; Rhee, J.G.; Lee, Y.J. Effects of low dose quercetin: Cancer cell-specific inhibition of cell cycle progression. J. Cell. Biochem. 2009, 106, 73-82. [CrossRef] [PubMed]

28. Ren, M.X.; Deng, X.H.; Ai, F.; Yuan, G.Y.; Song, H.Y. Effect of quercetin on the proliferation of the human ovarian cancer cell line SKOV-3 in vitro. Exp. Ther. Med. 2015, 10, 579-583. [CrossRef]

29. Hassan, S.K.; Mousa, A.M.; El-Sammad, N.M.; Abdel-Halim, A.H.; Khalil, W.K.; Elsayed, E.A.; Anwar, N.; Linscheid, M.W.; Moustafa, E.S.; Hashim, A.N.; et al. Antitumor activity of Cuphea ignea extract against benzo(a)pyrene-induced lung tumorigenesis in Swiss Albino mice. Toxicol. Rep. 2019, 6, 1071-1085. [CrossRef] [PubMed]

30. Tripathi, A.; Kumar, B.; Sagi, S.S. Prophylactic efficacy of Quercetin in ameliorating the hypoxia induced vascular leakage in lungs of rats. PLoS ONE 2019, 14, e0219075. [CrossRef] [PubMed]

31. Hayat, M.A. Principles and Techniques of Electron. Microscopy: Biological Applications, 4th ed.; Cambridge University Press: Edinburg, UK, 2000; pp. 37-59.

32. Rahmani, A.H.; Babiker, A.Y.; AlWanian, W.M.; Elsiddig, S.A.; Faragalla, H.E.; Aly, S.M. Association of cytokeratin and vimentin protein in the genesis of transitional cell carcinoma of urinary bladder patients. Dis. Markers 2015, 2015. [CrossRef]

33. Rahmani, A.; Alzohairy, M.; Khadri, H.; Mandal, A.K.; Rizvi, M.A. Expressional evaluation of vascular endothelial growth factor (VEGF) protein in urinary bladder carcinoma patients exposed to cigarette smoke. Int. J. Clin. Exp. Pathol. 2012, 5, 195. [PubMed]

34. Rahmani, A.; Alzohairy, M.; Babiker, A.Y.; Rizvi, M.A.; Elkarimahmad, H.G. Clinicopathological significance of PTEN and bcl2 expressions in oral squamous cell carcinoma. Int. J. Clin. Exp. Pathol. 2012, 5, 965.

35. Wang, C.C.; Yuan, J.R.; Wang, C.F.; Yang, N.; Chen, J.; Liu, D.; Song, J.; Feng, L.; Tan, X.B.; Jia, X.B. Anti-inflammatory effects of Phyllanthus emblica L on benzopyrene-induced precancerous lung lesion by regulating the IL-1 $\beta / \mathrm{miR}-101 / \mathrm{Lin} 28 \mathrm{~B}$ signaling pathway. Integr. Cancer Therapies 2017, 16, 505-515. [CrossRef]

36. Gaweł, S.; Wardas, M.; Niedworok, E.; Wardas, P. Malondialdehyde (MDA) as a lipid peroxidation marker. Wiad Lek. 2004, 57, 453-455. [PubMed]

37. Oke, G.O.; Abiodun, A.A.; Imafidon, C.E.; Monsi, B.F. Zingiber officinale (Roscoe) mitigates $\mathrm{CCl}_{4}$-induced liver histopathology and biochemical derangements through antioxidant, membrane-stabilizing and tissue-regenerating potentials. Toxicol. Rep. 2019, 6, 416-425. [CrossRef] [PubMed]

38. Parathodilllam, S.; Hussain, A.; Elizabeth, A.; Narayanankutty, A.; Raghavamenon, A.C. Natural combination of phenolic glycosides from fruits resists pro-oxidant insults to colon cells and enhances intrinsic antioxidant status in mice. Toxicol. Rep. 2019, 6, 703-711. [CrossRef] [PubMed]

39. Barnwal, P.; Vafa, A.; Afzal, S.M.; Shahid, A.; Hasan, S.K.; Alpashree Sultana, S. Benzo(a)pyrene induces lung toxicity and inflammation in mice: Prevention by carvacrol. Hum. Exp. Toxicol. 2018, 37, 752-761. [CrossRef] [PubMed]

40. Li, X.; He, S.; Gao, C.; Deng, H.; Liu, Y.; Li, C.; Yuan, L.; Luo, Y. Isoorientin attenuates benzo [a] pyrene-induced liver injury by inhibiting autophagy and pyroptosis in vitro and vivo. Food Agric. Immunol. 2019, 30, 841-861. [CrossRef]

41. Deng, C.; Dang, F.; Gao, J.; Zhao, H.; Qi, S.; Gao, M. Acute benzo[a]pyrene treatment causes different antioxidant response and DNA damage in liver, lung, brain, stomach and kidney. Heliyon 2018, 4, e00898. [CrossRef] 
42. Ali, R.; Shahid, A.; Ali, N.; Hasan, S.K.; Majed, F.; Sultana, S. Amelioration of benzo[a]pyrene-induced oxidative stress and pulmonary toxicity by naringenin in Wistar rats: A plausible role of COX-2 and NF-kappab. Hum. Exp. Toxicol. 2017, 36, 349-364. [CrossRef]

43. Rahimi, V.B.; Shirazinia, R.; Fereydouni, N.; Zamani, P.; Darroudi, S.; Sahebkar, A.H.; Askari, V.R. Comparison of honey and dextrose solution on post-operative peritoneal adhesion in rat model. Biomed. Pharmacother. 2017, 92, 849-855. [CrossRef] [PubMed]

44. Hu, J.; Zhang, Y.; Dong, L.; Wang, Z.; Chen, L.; Liang, D.; Shi, D.; Shan, X.; Liang, G. Design, Synthesis, and Biological Evaluation of Novel Quinazoline Derivatives as Anti-inflammatory Agents against Lipopolysaccharide-induced Acute Lung Injury in Rats. Chem. Biol. Drug Des. 2015, 85, 672-684. [CrossRef]

45. Libby, P. Inflammatory mechanisms: The molecular basis of inflammation and disease. Nutr. Rev. 2007, 65, S140-S146. [CrossRef] [PubMed]

46. Huang, R.; Zhong, T.; Wu, H. Quercetin protects against lipopolysaccharide-induced acute lung injury in rats through suppression of inflammation and oxidative stress. Arch. Med. Sci. 2015, 11, 427-432. [CrossRef] [PubMed]

47. Almatroodi, S.A.; Alrumaihi, F.; Alsahli, M.A.; Alhommrani, M.F.; Khan, A.; Rahmani, A.H. Curcumin, an Active Constituent of Turmeric Spice: Implication in the Prevention of Lung Injury Induced by Benzo(a) Pyrene (BaP) in Rats. Molecules 2020, $25,724$. [CrossRef]

48. Ravichandran, N.; Suresh, G.; Ramesh, B.; Siva, G.V. Fisetin, a novel flavonol attenuates benzo(a)pyrene-induced lung carcinogenesis in Swiss albino mice. Food Chem Toxicol. 2011, 49, 1141-1147. [CrossRef] [PubMed]

49. Islam, J.; Shree, A.; Afzal, S.M.; Vafa, A.; Sultana, S. Protective effect of Diosmin against benzo(a)pyrene-induced lung injury in Swiss Albino Mice. Environ. Toxicol. 2020, 35, 747-757. [CrossRef]

50. Yeo, C.D.; Kim, Y.A.; Lee, H.Y.; Kim, J.W.; Kim, S.J.; Lee, S.H.; Kim, Y.K. Roflumilast treatment inhibits lung carcinogenesis in benzo (a) pyrene-induced murine lung cancer model. Eur. J. Pharmacol. 2017, 812, 189-195. [CrossRef]

51. Li, F.; Bai, Y.; Zhao, M.; Huang, L.; Li, S.; Li, X.; Chen, Y. Quercetin inhibits vascular endothelial growth factor-induced choroidal and retinal angiogenesis in vitro. Ophthalmic. Res. 2015, 53, 109-116. [CrossRef]

52. Alzohairy, M.A.; Khan, A.A.; Alsahli, M.A.; Almatroodi, S.A.; Rahmani, A.H. Protective Effects of Thymoquinone, an Active Compound of Nigella sativa, on Rats with Benzo(a)pyrene-Induced Lung Injury through Regulation of Oxidative Stress and Inflammation. Molecules 2021, 26, 3218. [CrossRef]

53. Anandakumar, P.; Kamaraj, S.; Jagan, S.; Ramakrishnan, G.; Asokkumar, S.; Naveenkumar, C.; Raghunandhakumar, S.; Vanitha, M.K.; Devaki, T. The Anticancer Role of Capsaicin in Experimentally induced Lung Carcinogenesis. J. Pharmacopunct. 2015, 18, 19-25. [CrossRef]

54. Shahid, A.; Ali, R.; Ali, N.; Hasan, S.K.; Rashid, S.; Majed, F.; Sultana, S. Attenuation of genotoxicity, oxidative stress, apoptosis and inflammation by rutin in benzo (a) pyrene exposed lungs of mice: Plausible role of NF- $\mathrm{B}, \mathrm{TNF}-\alpha$ and Bcl-2. J. Complementary Integr. Med. 2016, 13, 17-29. [CrossRef] [PubMed]

55. Wang, L.; Chen, J.; Wang, B.; Wu, D.; Li, H.; Lu, H.; Wu, H.; Chai, Y. Protective effect of quercetin on lipopolysaccharide-induced acute lung injury in mice by inhibiting inflammatory cell influx. Exp. Biol. Med. 2014, 239, 1653-1662. [CrossRef] [PubMed] 